of those whose bodies have been donated for the cause of medical education and research and by first-year medical and dental students.

For many students this is the first occasion when they encounter the personal grief that surrounds bereavement. It also provides an occasion for the bereaved to be present at a funeral service which, because of the donation, they were unable to attend at the time of the death. The therapeutic value of an event such as a funeral (when people formally 'let go' of the dead person) is already well documented.

The funeral takes place in the modern university chapel. The relatives are seated. Staff and students occupy remaining seats and then stand four or five people deep around the walls.

The funeral constitutes a formal committal 'to the elements' of the deceased and is within the Christian tradition. One unlabelled coffin is brought into the university chapel for the service and a 'roll of honour' of those bodies going to the crematorium is read. Any donor who had specified there should be no Christian service after his or her death would have his or her wishes respected.

Hymns and prayers are selected to emphasise the theme of thanksgiving with the positive aspects of the donation being stressed. Ushers are selected from amongst the students, who will have had their Anatomy end-of-year examination either the previous afternoon or the same morning.

At the service itself many students are emotionally moved. Its immediate benefit in confronting them with the human reality of death is self-evident. Further, as the occasion when many of them come face to face with the reality of bereaved relatives its long-term significance must not be minimised. Relatives, also very moved by the occasion, always express considerable gratitude for the funeral.

Tea and coffee are served after the service in the chaplaincy and the chaplains and Anatomy Department staff circulate amongst the bereaved relatives. The Anatomy Department's Book of Remembrance is passed around the relatives. We consider detail such as this vitally important in the university's personal contact with the community in which it exists.

We know of similar funeral services in Aberdeen and St Andrews. Our experience of the event as a vital part of medical and dental formation in Dundee gives us the confidence to recommend it to other institutions so that its value may become more widely understood and its practice more widely shared.

ROBERT A GILLIES University Chaplain, The University of Dundee

\section{Jacob and his name: a lesson in the ethics of responsibility}

\section{IIK}

The stors of Jacoh, a name meaning decescer, and hu prelencic (o) be his brolher for an inheritance, is one of the uldest stories of the Western world (1) and may still provide a timely lesson for the necessity to take responsibility for whw we are and what we do. After presentung humselt as his brother Esau and reciving his father's blessing. Jacob fled to live for two decades with his mother's hrother. W'hen he returned herme and stopped by the stream Jalukk. he wrestled with an angel who asked him his name; Jacob replied, 'My name is Jacob'. The angel renamed him Isracl and shortly Esau received his hrowher hack. Jacioh's pretence only provided short-lerm gain and a longer period of loss, though it culminated in reunion and realisation (2).

Russell has stated:

The importance of precepts such as the Ien Commandments lies in the fact that they give simple rules, obedience to which will in almost all cases have better conscyucnces than disobedience; and the justification of the rules is not wholly independent of consequences' (3).

Jacoh did not have the benefit of the Tin Commandments (4), only of his conscience; a situation in which many physicians must find themselves in an era of a. fast-changing medical technology. Furthermore, rules cannot cover all exigencies that arise, and it is then necessary to fall back upon the decision of an individual conscience, the results of which can only be judged later. An example of this is presented by Veatch:

'Another ethical principle in addition to justice and promise-keeping that many formalists hold to be independent of consequences is that of truth-telling. As with the other principles, utilitarians argue that truth-telling is an operational principle designed to guarantee maximum benefit. When truth-telling does more harm than good . . . there is no obligation to tell the truth . . . telling the dying patient of his condition can be cruel and therefore wrong' (5).

The decision at the bedside often remains an individual one. In Jacob's case, we know he was acting from selfinterest for which he faced a period of atonement.

From Jacob's story and the Ten Commandments we come to the teachings of Christ. As Garrison has put it:

'The chief glory of medieval medicine was undoubtedly in the organisation of hospitals and sick-nursing, which had its origins in the teachings of Christ ... the spirit of antiquity toward sickness and misfortune was not one of compassion, and the credit of ministering to human suffering on an extended scale belongs to Christianity' (6).

'For the law was given by Moses, but grace and truth came by Jesus Christ' (7).

The teachings of Christ reflect the lesson of Jacob: that it is individual action with its consequences in conscience that provide the foundation for both the development and application of ethical laws. The physician at the bedside must follow not only established ethical sanctions, but often must act and abide by an individual decision.

Addenum: Following the completion and sending of this letter, I am in receipt of Dr Michael J Newton's article in the December issue of this journal, Mora dilemmas in surgical training: inten and the case for ethical ambiguity. Our paths have crossed, for our thinking is neither dissimilar nor mutually exclusive. I hope the readers of this journal will find the ideas presented stimulating enough to engage in reply.

\section{References}

(1) Genesis 27, 32.

(2) Watkins K G. From a letter to me outlining a sermon he had given.

(3) Russell B. The elements of ethics. In: Russell B . Philosophical essays. New York: Simon and Schuster, 1986: 29.

(4) Exodus 20

(5) Veatch R M. Case studies in medical ethics. Cambridge, Mass: Harvard University Press, 1977: 9.

:6) Garrison F H. An introduction to the history of medicine. (4th ed) W B Saunders Co, 1929: 176.

(7) John 1: 17.

JOHN HENRY McWHORTER, MD McWhorter, West Virginia 2640

USA 